\title{
Effects of different cooking methods on the bioactivities of some spices
}

\author{
Eric Wei Chiang Chan*, Hor Jeann Chan, Joo Ee Lim, Sook Han Yik, Su Fun Tan, Pik Chean Goh, \\ Kim Yee Yap, Siew Ying Yee
}

Faculty of Applied Sciences, UCSI University, 56000 Cheras, Kuala Lumpur, Malaysia

\section{A B S T R A C T}

\begin{abstract}
In this study, the antioxidant, anti-tyrosinase, antibacterial and anti-quorum sensing (QS) properties of selected spices, and the effects of microwave, blanching and boiling were analysed. Of the spices screened for antioxidant properties, clove had the highest values followed by cinnamon with poppy having the lowest values. In general, cinnamon, star anise and cumin showed declines in antioxidant properties following cooking but clove and cardamom showed increases. Leaching of phenolic compounds into the water during blanching and boiling was most evident in cumin and cardamom. Of the six spices screened, cinnamon and cumin had the strongest anti-tyrosinase activity. Microwave $(1 \mathrm{~min}$ ) resulted in a significant loss in activity for clove and star anise. For microwave (5 min), a significant gain in activity was observed in cardamom. In general, the anti-tyrosinase activity of the spices remained unchanged following blanching and boiling. Of the five spices screened for antibacterial activity, clove showed broad-spectrum inhibition. Cardamom and cinnamon were only effective against Gram-positive bacteria. Cinnamon only inhibited Escherichia coli after cooking. Clove and cinnamon showed anti-QS activity against Chromobacterium violaceum with violacein inhibition zones of 15 and $9 \mathrm{~mm}$, and minimum inhibitory doses of 0.5 and $2 \mathrm{mg} / \mathrm{disc}$, respectively. The activity was retained after heat treatment. Besides the culinary benefits of spices, this study has demonstrated their therapeutic benefits even after cooking.
\end{abstract}

Keywords: Antioxidant; Anti-tyrosinase; Antibacterial; Anti-quorum sensing; Microwave; Blanching; Boiling

\section{INTRODUCTION}

With a history as long as human civilization, and the inspiration of war, exploration and trade, spices have been used for flavouring, seasoning and preserving foods. Spices are usually dried roots, barks or seeds used whole, crushed or powdered, while herbs are usually fresh leaves, stems or flowers of herbaceous plants (Balasasirekha, 2014). Acknowledging that a spicy life is a healthy one, even a little spice in our diet can boost our immune system, and decrease the risk of high blood pressure, cardiovascular diseases and cancer. Many spices used in traditional medicine are recognised to have medicinal properties and health benefits such as antioxidant, anti-inflammatory, antimicrobial, hypolipidemic, antimutagenic and anticarcinogenic activities (Shan et al., 2005).

Spices are the heart and soul of cooking in most parts of Asia, renowned for their great variety of hot and spicy cuisines. No country in the world produces as much spices as India with an estimated annual production of 2.5 million tons, valued at 3 billion USD (Balasasirekha, 2014). In Indonesia, half of the world's production of clove is used to make kretek cigarettes, a complex blend of tobacco and clove (Milind and Deepa, 2011). Most dishes in South and Southeast Asia, especially the curries and soups, are prepared using a generous combination of spices and herbs as ingredients. Indian spices include turmeric, cinnamon, clove, star anise, cardamom, coriander and cumin. Spices and herbs commonly used in Thai and Malaysian dishes include chilli, ginger, lemongrass, basil, kaffir lime and smartweed. In Malaysia, the multi-ethnic society of Malays, Chinese, Indians and other ethnic groups contributes to the country's rich diversity of cuisines (Yoshino, 2010).

Although the antioxidant and antibacterial properties of spices are well studied, there is little information on their anti-tyrosinase and anti-quorum sensing (QS) activities. The effects of cooking on these bioactivities have not been investigated. In this study, the antioxidant, anti-tyrosinase,

\footnotetext{
*Corresponding author:

Eric Wei Chiang Chan, Faculty of Applied Sciences, UCSI University, 56000 Cheras, Kuala Lumpur, Malaysia.

E-mail: chanwc@ucsiuniversity.edu.my; erchan@yahoo.com
} 
antibacterial and anti-QS properties of selected spices, and the effects of different cooking methods (microwave, blanching and boiling) were assessed. The effects of heat treatment on the anti-tyrosinase and anti-QS properties of spices are reported for the first time.

\section{MATERIALS AND METHODS}

\section{Spices}

Twelve spices were screened for phenolic contents and antioxidant activities. The spices were basil (Ocimum basilicum), black pepper (Piper nigrum), cardamom (Elettaria cardamomum), cinnamon (Cinnamomum aromaticum), clove (Sysygium aromaticum), coriander (Coriandrum sativum), cumin (Cuminum cyminum), fennel (Foeniculum vulgare), fenugreek (Trigonella foenum-graecum), mustard (Brassica nigra), poppy (Papaver somniferum) and star anise (Illicium verum). The effects of cooking on the antioxidant, anti-tyrosinase, antibacterial and anti-QS properties of cardamom, cinnamon, clove, cumin and star anise were evaluated.

\section{Extraction and processing}

For antioxidant properties, raw $(1 \mathrm{~g})$ and processed $(0.3 \mathrm{~g})$ spices were powdered with liquid nitrogen in a mortar and extracted with $50 \mathrm{~mL}$ of methanol with continuous shaking for $1 \mathrm{~h}$ at room temperature. Extracts were filtered under reduced pressure and stored at $4{ }^{\circ} \mathrm{C}$ for further analysis.

For anti-tyrosinase and antibacterial activities, raw (10 g) and processed ( $3 \mathrm{~g})$ spices were powdered with liquid nitrogen in a mortar and extracted with $100 \mathrm{~mL}$ of methanol, three times for $1 \mathrm{~h}$ each time. After swirling continuously in an orbital shaker, extracts were filtered and stored at $4{ }^{\circ} \mathrm{C}$ for further analysis.

Spices were blanched and boiled by immersing $1 \mathrm{~g}$ of sample in $50 \mathrm{~mL}$ of boiling water for 1 and $5 \mathrm{~min}$, respectively. The samples were sieved, wiped dry and extracted, while the water was kept for analysis of phenolic content. For microwave treatment, spices $(1 \mathrm{~g})$ were heated in a microwave oven $(230-240 \mathrm{~V}, 50 \mathrm{~Hz})$ for 1 and $5 \mathrm{~min}$.

\section{Antioxidant assays}

Spices were analysed for phenolic contents (total phenolic content, total flavonoid content and caffeoylquinic acid content) using the Folin-Ciocalteu, aluminium chloride and molybdate assays (Arazo et al., 2011; Chan et al., 2012, 2014). Antioxidant activities (free radical scavenging activity, ferric reducing power and ferrous ion chelating ability) were measured using the DPPH radical scavenging, potassium ferricyanide and ferrozine assays.

In the Folin-Ciocalteu (FC) assay, extracts $(300 \mu \mathrm{L})$ were introduced into test tubes wrapped with aluminium foil, followed by $1.5 \mathrm{~mL}$ of $\mathrm{FC}$ reagent (10 times dilution) and $1.2 \mathrm{~mL}$ of sodium carbonate $(7.5 \%, \mathrm{w} / \mathrm{v})$. After incubating for $30 \mathrm{~min}$ in the dark, absorbance was read at $765 \mathrm{~nm}$. Total phenolic content (TPC) was expressed as gallic acid equivalent (GAE) in $\mathrm{mg}$ per $100 \mathrm{~g}$ of sample.

In the aluminium chloride assay, extracts $(1 \mathrm{~mL})$ were introduced into test tubes containing $4 \mathrm{~mL}$ of water. Then, $0.3 \mathrm{~mL}$ of $5 \%$ sodium nitrite was added, followed by $0.3 \mathrm{~mL}$ of $10 \%$ aluminium chloride, $2 \mathrm{~mL}$ of sodium hydroxide solution and $2.4 \mathrm{~mL}$ of water to make up to $10 \mathrm{~mL}$. After mixing well and incubated at room temperature for $10 \mathrm{~min}$, absorbance was read at $415 \mathrm{~nm}$ against a sample blank of $1 \mathrm{~mL}$ of the respective extracts with $9 \mathrm{~mL}$ of water. Total flavonoid content (TFC) was expressed as quercetin equivalent (QE) in $\mathrm{mg} / 100 \mathrm{~g}$ of sample.

In the molybdate assay, molybdate reagent was prepared by dissolving $16.5 \mathrm{~g}$ sodium molybdate, $8.0 \mathrm{~g}$ dipotassium hydrogen phosphate and 7.9 g potassium dihydrogen phosphate in $1 \mathrm{~L}$ of water. The reagent $(2.7 \mathrm{~mL})$ was added to the extract $(0.3 \mathrm{~mL})$, mixed and incubated at room temperature for $10 \mathrm{~min}$. Absorbance was read at $370 \mathrm{~nm}$ against a sample blank of $0.3 \mathrm{~mL}$ of the extracts with $2.7 \mathrm{~mL}$ of water. Caffeoylquinic acid content (CQAC) was expressed as chlorogenic acid equivalent (CGAE) in $\mathrm{mg} / 100 \mathrm{~g}$ of sample.

In the 2,2-diphenyl-1-picrylhydrazyl (DPPH) assay, different dilutions of extracts $(1 \mathrm{~mL})$ were added to $2 \mathrm{~mL}$ of DPPH (5.9 mg in $100 \mathrm{~mL}$ methanol). Absorbance was read at $517 \mathrm{~nm}$ after $30 \mathrm{~min}$. The $\mathrm{IC}_{50}$ was expressed as ascorbic acid equivalent antioxidant capacity (AEAC) in $\mathrm{mg}$ ascorbic acid (AA)/100 g of sample, which was calculated as $\mathrm{IC}_{50}$ of ascorbic acid/ $/ \mathrm{IC}_{50}$ of samplex $10^{5}$ where the $\mathrm{IC}_{50}$ of ascorbic acid was $0.00387 \mathrm{mg} / \mathrm{mL}$.

In the potassium ferricyanide assay, different dilutions of extracts $(1 \mathrm{~mL})$ were added to $2.5 \mathrm{~mL}$ phosphate buffer $(0.2 \mathrm{M}, \mathrm{pH} 6.6)$ and $2.5 \mathrm{~mL}$ of potassium ferricyanide $(1 \%, \mathrm{w} / \mathrm{v})$. The mixture was incubated at $50^{\circ} \mathrm{C}$ for $20 \mathrm{~min}$. After adding trichloroacetic acid solution $(2.5 \mathrm{~mL}, 10 \%$, $\mathrm{w} / \mathrm{v}$ ), the mixture was separated into aliquots of $2.5 \mathrm{~mL}$, and diluted with $2.5 \mathrm{~mL}$ of water. Ferric chloride solution $(500 \mathrm{~mL}, 0.1 \%, \mathrm{w} / \mathrm{v})$ was added to each diluted aliquot and absorbance was read at $700 \mathrm{~nm}$ after $30 \mathrm{~min}$. Ferric reducing power (FRP) was expressed as $\mathrm{mg}$ GAE/100 g. The calibration equation for gallic acid was $y=16.767 \mathrm{x}$ $\left(R^{2}=0.9974\right)$, where $y$ is the absorbance and $x$ is the GA concentration in $\mathrm{mg} / \mathrm{mL}$.

In the ferrozine assay, different dilutions of extracts $(1 \mathrm{~mL})$ were mixed with $\mathrm{FeSO}_{4}(0.1 \mathrm{mM}, 1 \mathrm{~mL})$ and ferrozine $(0.25 \mathrm{mM}, 1 \mathrm{~mL})$. Absorbance was read 
at $562 \mathrm{~nm}$ after $10 \mathrm{~min}$. Ferrous ion chelating (FIC) ability $=\left(1-\mathrm{A}_{\text {sample }} / \mathrm{A}_{\text {contro }}\right) \times 100 \%$ and expressed as chelating efficiency concentration $\left(\mathrm{CEC}_{50}\right)$ in $\mathrm{mg} / \mathrm{mL}$ or the effective concentration of extract needed to chelate ferrous ions by $50 \%$.

\section{Anti-tyrosinase assay}

Tyrosinase inhibition of spices was determined using the dopachrome assay with L-3,4-dihydroxyphenylalanine (L-DOPA) as substrate (Masuda et al., 2005; Tan and Chan, 2014). Concentration of extracts used was $2.5 \mathrm{mg} / \mathrm{mL}$. The assay was conducted in a 96-well microtiter plate using a plate reader to measure absorbance at $475 \mathrm{~nm}$ with $700 \mathrm{~nm}$ as reference. Samples were dissolved in DMSO. Each well was filled with $40 \mu \mathrm{L}$ of sample with $80 \mu \mathrm{L}$ of phosphate buffer $(0.1 \mathrm{M}, \mathrm{pH} 6.8), 40 \mu \mathrm{L}$ of tyrosinase (31 units $/ \mathrm{mL}$ ) and $40 \mu \mathrm{L}$ of L-DOPA $(2.5 \mathrm{mM})$. Each sample was accompanied by a blank that had all the components except L-DOPA. Results were compared with a control consisting of DMSO in place of sample. Tyrosinase inhibition was calculated as $\left(\mathrm{A}_{\text {control }}-\mathrm{A}_{\text {sample }}\right) / \mathrm{A}_{\text {control }} \times 100 \%$.

\section{Antibacterial activity}

The antibacterial activity of spices was assessed using the disc-diffusion method (Chan et al., 2012), and tested against Gram-positive Bacillus cereus (ATCC 11778), Micrococcus luteus (ATCC 10240) and Staphylococcus aureus, and Gramnegative Escherichia coli, Salmonella enterica and Pseudomonas aeruginosa. The identity of the bacterial species was verified using VITEK ${ } 2$ microbial identification system. Agar cultures of bacteria were prepared and inoculums (100 $\mu \mathrm{L}$ ) were spread evenly onto $20 \mathrm{~mL}$ Mueller-Hinton agar set in $90 \mathrm{~mm}$ Petri dishes using a sterile cotton swab. Paper discs (6 $\mathrm{mm}$ diameter) were impregnated with twofold dilution of extract, starting from $2 \mathrm{mg} /$ disc, using a micropipette. After incubation overnight at $37^{\circ} \mathrm{C}$, the minimum inhibitory dose (MID) in mg of extract per disc required to show a zone of inhibition was recorded.

\section{Anti-quorum sensing activity}

The anti-QS activity of spices was assessed using the discdiffusion assay and tested against Chromobacterium violaceum (CV, ATCC 12472) based on the diameter of inhibition zone (DIZ) of violacein production and minimum inhibition dose (MID) of CV growth (Tan et al., 2015). The concentration of extracts used was $1 \mathrm{mg} /$ disc for DIZ and $2 \mathrm{mg} /$ disc for MID. CV grown in LB broth $\left(\mathrm{OD}_{720} 1.00 \mathrm{~A}\right)$ was inoculated onto $75 \%$ semi-solid LB agar plates. Paper discs $(6 \mathrm{~mm}$ diameter) impregnated with extracts were transferred onto the inoculated agar. After incubation overnight at $28^{\circ} \mathrm{C}$, the plates were observed and measured for DIZ in $\mathrm{mm}$ of violacein production and MID for CV growth inhibition. The inhibition zone of violacein production was visible as an opaque halo around the impregnated disc against a purple violacein background, which indicated uninhibited growth of bacterial cells but an absence of violacein pigment. The inhibition zone of $\mathrm{CV}$ growth appeared as a clear halo around the impregnated disc. The amount used to impregnate per disc was then reduced two-fold until no inhibition zone was visible. The least amount of extract per disc required was recorded as MID.

\section{Statistical analysis}

All experiments were done in triplicate $(n=3)$ and results were expressed as means \pm standard deviations. Analysis of variance was analysed using the Tukey HSD test based on significant difference of $p<0.05$.

\section{RESULTS AND DISCUSSION}

\section{Antioxidant properties}

Of the 12 spices screened for antioxidant properties, clove and poppy had the highest and lowest values, respectively (Table 1). TPC and AEAC of clove were 2.1 and 2.3 fold those of cinnamon, which ranked second. TPC and TFC were not detected in poppy and star anise, respectively. There was strong positive correlation between TPC and primary antioxidant activities of $\operatorname{AEAC}\left(R^{2}=0.985\right)$ and $\mathrm{FRP}\left(R^{2}=0.950\right)$, but not between TPC and secondary activity of $\mathrm{CEC}_{50}\left(R^{2}=0.086\right)$.

Based on antioxidant properties, the spices studied can be categorised into the very high category (clove and cinnamon), high category (black pepper, star anise and cumin), low category (fennel, basil, mustard, coriander, fenugreek and cardamom), and very low category (poppy). Data of an earlier study by Shan et al. $(2005,2007)$ on the antioxidant capacity of 26 spices also showed that clove and cinnamon had the highest values, and poppy had the lowest values based on TPC and total equivalent antioxidant capacity. Another study also reported that clove had the strongest radical scavenging activity followed by allspice and cinnamon out of 16 spices (Khatun et al., 2006). Based on lipid peroxidation inhibition, clove ranked first followed by cinnamon (Shobana and Naidu, 2000).

Cinnamon, star anise and cumin showed declines in antioxidant properties following MW (1 min), MW (5 min), blanching and boiling but clove and cardamom showed increases (Table 2). The most drastic decline was observed in boiled cumin with TPC and AEAC declining by $66 \%$ and $76 \%$, respectively. Significant gains were evident in cardamom and clove. In support of findings of this study, Khatun et al. (2006) have earlier reported significantly stronger radical scavenging activity in clove and cardamom even after boiling for $6 \mathrm{~h}$, suggesting that the active components are relatively stable during thermal treatment. 
Table 1: Phenolic contents and antioxidant activities of 12 spices

\begin{tabular}{|c|c|c|c|c|c|c|}
\hline \multirow[t]{2}{*}{ Spice } & \multicolumn{3}{|c|}{ Phenolic content } & \multicolumn{3}{|c|}{ Antioxidant activity } \\
\hline & TPC & TFC & CQAC & AEAC & FRP & $\mathrm{CEC}_{50}$ \\
\hline Clove & $16400 \pm 990$ & $937 \pm 68$ & $2010 \pm 93$ & $24100 \pm 2000$ & $11000 \pm 319$ & $1.4 \pm 0.2$ \\
\hline Cinnamon & $7740 \pm 1550$ & $29 \pm 3$ & $838 \pm 205$ & $10500 \pm 4560$ & $3030 \pm 623$ & $6.8 \pm 1.2$ \\
\hline Black pepper & $2440 \pm 61$ & $273 \pm 77$ & $1220 \pm 276$ & $434 \pm 49$ & $180 \pm 35$ & $15 \pm 6.2$ \\
\hline Star anise & $2362 \pm 571$ & ND & $555 \pm 56$ & $2823 \pm 29$ & NA & $43 \pm 12$ \\
\hline Cumin & $1058 \pm 164$ & $761 \pm 253$ & $449 \pm 61$ & $1011 \pm 37$ & NA & $4.3 \pm 0.0$ \\
\hline Fennel & $472 \pm 36$ & $205 \pm 13$ & $310 \pm 20$ & $547 \pm 96$ & $281 \pm 7$ & $2.3 \pm 0.3$ \\
\hline Basil & $433 \pm 51$ & $78 \pm 4$ & $284 \pm 42$ & $435 \pm 105$ & $444 \pm 58$ & $14 \pm 8.7$ \\
\hline Mustard & $390 \pm 7$ & $20 \pm 3$ & $34 \pm 5$ & $278 \pm 15$ & $285 \pm 19$ & $22 \pm 11$ \\
\hline Coriander & $376 \pm 38$ & $152 \pm 20$ & $122 \pm 10$ & $255 \pm 24$ & $256 \pm 25$ & $4.4 \pm 0.8$ \\
\hline Fenugreek & $300 \pm 2$ & $243 \pm 9$ & $123 \pm 17$ & $173 \pm 4$ & $114 \pm 5$ & $4.0 \pm 1.1$ \\
\hline Cardamom & $217 \pm 33$ & $64 \pm 11$ & $86 \pm 39$ & $132 \pm 16$ & $191 \pm 13$ & $6.7 \pm 2.2$ \\
\hline Poppy & ND & $3 \pm 1$ & $23 \pm 4$ & $28 \pm 6$ & $39 \pm 6.4$ & $6.0 \pm 0.5$ \\
\hline
\end{tabular}

Abbreviations: TPC=Total phenolic content (mg GAE/100 g), TFC=Total flavonoid content (mg QE/100 g), CQAC=Caffeoylquinic acid content (mg CGAE/100 g), $\mathrm{AEAC}=$ Ascorbic acid equivalent antioxidant capacity ( $\mathrm{mg} \mathrm{AA} / 100 \mathrm{~g}), \mathrm{FRP}=$ Ferric reducing power ( $\mathrm{mg} \mathrm{GAE} / 100 \mathrm{~g}), \mathrm{CEC}_{50}=$ Median chelating efficiency concentration $(\mathrm{mg} / \mathrm{mL}), \mathrm{GAE}=\mathrm{Gallic}$ acid equivalent, $\mathrm{QE}=$ Quercetin equivalent, $\mathrm{CGAE}=\mathrm{Ch}$ lorogenic acid equivalent, $\mathrm{AA}=\mathrm{Ascorbic}$ acid, $\mathrm{ND}=\mathrm{Not}$ detected and $\mathrm{NA}=$ Not available. Lower $\mathrm{CEC}_{50}$ values indicate stronger ferrous ion chelating (FIC) ability

Table 2: Gain or loss in antioxidant properties of cooked spices

\begin{tabular}{llccc}
\hline Spice & Treatment & \multicolumn{3}{c}{ Percentage gain (+) or loss $(-)$} \\
\cline { 3 - 5 } & & TPC & TPC+water & AEAC \\
\hline Clove & MW (1 min) & $+64^{*}$ & & +8 \\
& MW (5 min) & $+74^{*}$ & & $+21^{*}$ \\
& Blanching & $+39^{*}$ & $+44^{*}$ & $+21^{*}$ \\
& Boiling & +23 & $+34^{*}$ & $+22^{*}$ \\
Cinnamon & MW (1 min) & -9 & & $-30^{*}$ \\
& MW (5 min) & $-29^{*}$ & & $-59^{*}$ \\
& Blanching & -3 & +4 & +5 \\
\multirow{5}{*}{ Star anise } & Boiling & $-29^{*}$ & $-26^{*}$ & $-46^{*}$ \\
& MW (1 min) & -17 & & $-75^{*}$ \\
& MW (5 min) & $-59^{*}$ & & $-78^{*}$ \\
& Blanching & +9 & +18 & $-36^{*}$ \\
& Boiling & -10 & +8 & $-43^{*}$ \\
& MW (1 min) & -9 & & $-26^{*}$ \\
& MW (5 min) & +9 & & $-23^{*}$ \\
& Blanching & $-49^{*}$ & $+36^{*}$ & $-58^{*}$ \\
& Boiling & $-66^{*}$ & +10 & $-76^{*}$ \\
Cardamom & MW (1 min) & $+25^{*}$ & & $+58^{*}$ \\
& MW (5 min) & $+144^{*}$ & & $+217^{*}$ \\
& Blanching & $+51^{*}$ & $+74^{*}$ & -5 \\
& Boiling & $+41^{*}$ & $+114^{*}$ & -6 \\
\hline
\end{tabular}

Abbreviations: TPC=Total phenolic content (mg GAE/100 g), AEAC=Ascorbic acid equivalent antioxidant capacity (mg AA/100 g), $\mathrm{MW}=$ Microwave, $\mathrm{GAE}=\mathrm{Gallic}$ acid equivalent and $\mathrm{AA}=\mathrm{Ascorbic}$ acid. Values with asterisks show significant gain or loss in properties $(p<0.05)$ compared to raw spices. Values of TPC+water are those of spices including those of the water used for blanching or boiling

There was substantial leaching of phenolic compounds into the water during blanching and boiling, which was most evident in cumin and cardamom. By including the TPC value of the water used for blanching, the overall TPC value increased from $-49 \%$ to $+36 \%$ for cumin and from $+51 \%$ to $+74 \%$ for cardamom. For boiling, the overall TPC value increased from $-66 \%$ to $+10 \%$ for cumin and from $+41 \%$ to $+114 \%$ for cardamom.

Processing methods are known to have variable effects on the antioxidant properties of plant samples. Effects include little or no change, significant losses, or enhancement
(Nicoli et al., 1999). Studies have reported losses and gains in phenolic contents and antioxidant activities of plant samples following thermal treatments. Losses were mainly reported in vegetables (Zhang and Hamauzu, 2004; Ismail et al., 2004; Roy et al., 2007). Declines in antioxidant properties have been attributed to degradative enzymes, thermal degradation of phytochemicals, and to loss of antioxidant enzyme activities (Larrauri et al., 1997; Lim and Murtijaya, 2007; Chan et al., 2013). Increments in antioxidant activities following by thermal treatments have been reported in tomato (Dewanto et al., 2002a), sweet corn (Dewanto et al., 2002b), Shiitake mushroom (Choi et al., 2006), ginseng (Kang et al., 2006) and potato (Bembem and Sadana, 2013). Enhancement of antioxidant properties has been attributed to the breakdown of cellular constituents, which releases bound phenolic compounds and to the formation of new compounds with enhanced antioxidant properties (Dewanto et al., 2002a, 2002b; Tomaino et al., 2005; Chan et al., 2013).

Turkmen et al. (2005) commented that the effects of cooking on the antioxidant properties of vegetables depend on the type and not on the method of cooking. However, Saikia and Mahanta (2013) found both positive and negative impacts on the antioxidant properties of vegetables, depending on the cooking method employed and type of vegetable. Drying treatments can have variable effects on the antioxidant properties of herbs (Chan et al., 2013, 2014). The same herb can respond differently to different drying treatments e.g. the antioxidant properties of microwaveheated betel leaves were significantly higher than fresh leaves but blanched leaves showed significant declines (Tan and Chan, 2014). Due to the complexity of the effects of cooking and other thermal treatments, it is suggested that a wide range of antioxidant properties and samples need to be analysed before one can draw any useful conclusions. 


\section{Anti-tyrosinase activity}

Of the six spices screened, cinnamon and cumin had the strongest anti-tyrosinase activity (Table 3). Microwave $(1 \mathrm{~min})$ resulted in significant loss in activity for clove $(-35 \%)$ and star anise $(-30 \%)$. For microwave ( $5 \mathrm{~min})$, significant gain in activity was observed in cardamom $(+53 \%)$. In general, the anti-tyrosinase activity of the spices remained unchanged following blanching and boiling. Tan and Chan (2014) reported that microwave-treated cashew leaves (49\%) showed a significant increase in tyrosinase inhibition as compared to fresh leaves (40\%). Blanched leaves (44\%) had comparable values.

\section{Antibacterial activity}

Of the five spices screened, clove showed broad-spectrum antibacterial activity against all six bacteria with MID of $0.25-1.00 \mathrm{mg} /$ disc (Table 4). After cooking, clove retained its antibacterial activity against $M$. luteus, $S$. aureus, B. cereus and E. coli. Activity was lost against $S$. enterica following microwave ( $5 \mathrm{~min}$ ) and boiling. Against $P$. aeruginosa, there was no activity after cooking. Raw and cooked cardamom was effective against Gram-positive bacteria of M. luteus, $S$. aureus and B. cereus. Those of cinnamon showed no

Table 3: Tyrosinase inhibition (\%) of raw and cooked spices

\begin{tabular}{|c|c|c|c|c|c|}
\hline Spice & Raw & $\begin{array}{l}\text { Microwave } \\
\text { (1 min) }\end{array}$ & $\begin{array}{l}\text { Microwave } \\
\text { (5 min) }\end{array}$ & $\begin{array}{l}\text { Blanching } \\
\text { (1 min) }\end{array}$ & $\begin{array}{l}\text { Boiling } \\
\text { (5 min) }\end{array}$ \\
\hline Cinnamon & $45 \pm 5$ & $35 \pm 5$ & $37 \pm 4$ & $42 \pm 4$ & $40 \pm 5$ \\
\hline Cumin & $42 \pm 3$ & $46 \pm 2$ & $40 \pm 2$ & $39 \pm 4$ & $45 \pm 1$ \\
\hline Clove & $31 \pm 5$ & $20 \pm 4^{*}$ & $28 \pm 5$ & $26 \pm 4$ & $23 \pm 5$ \\
\hline Star anise & $27 \pm 2$ & $19 \pm 2^{*}$ & $25 \pm 2$ & $25 \pm 2$ & $29 \pm 3$ \\
\hline Fennel & $23 \pm 5$ & $26 \pm 7$ & $28 \pm 5$ & $21 \pm 8$ & $15 \pm 7$ \\
\hline Cardamom & $17 \pm 4$ & $18 \pm 5$ & $26 \pm 4^{*}$ & $14 \pm 4$ & $19 \pm 5$ \\
\hline
\end{tabular}

Values with asterisks show significant gain or loss in tyrosinase inhibition $(p<0.05)$ compared to the raw spices. Concentration of extracts used was $2.5 \mathrm{mg} / \mathrm{mL}$ activity against $S$. aureus. Interestingly, cinnamon only inhibited Gram-negative E. coli after cooking. Cumin and star anise did not show any antibacterial activity.

Findings of this study are comparable with earlier reports. Using the agar well diffusion method, Mishra and Behal (2010) tested the antibacterial activity of four spices against five bacteria, and reported that cardamom and cinnamon exhibited antibacterial activity with DIZ of 13-21 $\mathrm{mm}$ and 12-18 $\mathrm{mm}$, respectively. Sethi et al. (2013) tested the antibacterial activity of seven spices against eight food-borne bacteria using the agar well diffusion method for zones of inhibition and the agar dilution method for minimum inhibitory concentration (MIC). Their results showed that clove and cumin inhibited all bacteria tested. There is disparity in cumin, which showed negative activity in our study. This could be due to the differences in the assays, extract concentrations and bacterial species used.

\section{Anti-quorum sensing activity}

Of the five spices assessed, clove and cinnamon showed anti-QS activity with VIZ of 15 and $9 \mathrm{~mm}$, and MID of 0.5 and $2 \mathrm{mg} /$ disc, respectively (Table 5). After cooking, their values were $15-20 \mathrm{~mm}$ and $0.5 \mathrm{mg} /$ disc for clove and $9.0-10 \mathrm{~mm} 0.25-0.5 \mathrm{mg} /$ disc for cinnamon. The results indicated that the anti-QS activity was stronger in clove than cinnamon. Cardamom, cumin and star anise did not show any QS inhibition. Of these spices, anti-QS activity has been reported in clove (Khan et al., 2009; Aparna et al., 2014a), cinnamon (Apriliani et al., 2013; Aparna et al., 2014b) and cumin (Packiavathy et al., 2012). Besides spices, anti-QS activity has also been reported in herbs including those used in traditional Chinese medicine (Koh and Tham, 2011).

Table 4: Antibacterial activity of raw and cooked spices

\begin{tabular}{|c|c|c|c|c|c|c|}
\hline \multirow{3}{*}{$\begin{array}{l}\text { Spice and } \\
\text { treatment }\end{array}$} & \multicolumn{6}{|c|}{ Minimum inhibitory dose (mg/disc) } \\
\hline & \multicolumn{3}{|c|}{ Gram-positive bacteria } & \multicolumn{3}{|c|}{ Gram-negative bacteria } \\
\hline & M. Iuteus & S. aureus & B. cereus & E. coli & S. enterica & P. aeruginosa \\
\hline Clove & 0.25 & 0.50 & 0.50 & 0.50 & 1.00 & 1.00 \\
\hline MW (1 min) & 0.25 & 1.00 & 1.00 & 2.00 & 2.00 & - \\
\hline MW (5 min) & 0.25 & 1.00 & 1.00 & 2.00 & - & - \\
\hline Blanching & 0.25 & 1.00 & 1.00 & 2.00 & 2.00 & - \\
\hline Boiling & 0.25 & 1.00 & 1.00 & 2.00 & - & - \\
\hline Cardamom & 0.50 & 0.25 & 0.13 & - & - & - \\
\hline MW (1 min) & 0.50 & 0.03 & 0.06 & - & - & - \\
\hline MW (5 min) & 0.50 & 0.06 & 0.06 & - & - & - \\
\hline Blanching & 0.50 & 0.06 & 0.06 & - & - & - \\
\hline Boiling & 0.50 & 0.06 & 0.06 & - & - & - \\
\hline Cinnamon & 0.50 & - & 2.00 & - & - & - \\
\hline MW (1 min) & 2.00 & - & 2.00 & 2.00 & - & - \\
\hline MW (5 min) & 0.25 & - & 2.00 & 2.00 & - & - \\
\hline Blanching & 0.25 & - & 1.00 & 1.00 & - & - \\
\hline Boiling & 0.25 & - & 1.00 & 2.00 & - & - \\
\hline
\end{tabular}

Cumin and star anise did not display any antibacterial activity against the bacteria tested. Extract concentration used for determining minimum inhibitory dose was $2 \mathrm{mg} / \mathrm{disc}$ 
Table 5: Quorum sensing inhibition of raw and cooked spices

\begin{tabular}{|c|c|c|c|c|c|c|}
\hline Spice & $\begin{array}{l}\text { QS } \\
\text { inhibition }\end{array}$ & Raw & $\begin{array}{c}\text { MW } \\
(1 \mathrm{~min}) \\
\end{array}$ & $\begin{array}{c}\text { MW } \\
(5 \mathrm{~min})\end{array}$ & Blanching & Boiling \\
\hline Clove & $\begin{array}{l}\text { VIZ } \\
\text { MID }\end{array}$ & $\begin{array}{c}15 \pm 0.6 \\
0.50\end{array}$ & $\begin{array}{c}20 \pm 1.5 \\
0.50\end{array}$ & $\begin{array}{c}15 \pm 1.0 \\
0.50\end{array}$ & $\begin{array}{c}15 \pm 1.5 \\
0.50\end{array}$ & $\begin{array}{c}19 \pm 0.6 \\
0.50\end{array}$ \\
\hline Cinnamon & $\begin{array}{l}\text { VIZ } \\
\text { MID }\end{array}$ & $\begin{array}{c}9.0 \pm 0.6 \\
2.00\end{array}$ & $\begin{array}{c}9.0 \pm 0.6 \\
0.25\end{array}$ & $\begin{array}{c}10 \pm 2.0 \\
0.25\end{array}$ & $\begin{array}{c}9.0 \pm 0.7 \\
0.25\end{array}$ & $\begin{array}{c}9.0 \pm 0.7 \\
0.50\end{array}$ \\
\hline
\end{tabular}

Abbreviations: $\mathrm{MW}=$ Microwave, $\mathrm{QS}=\mathrm{Quorum}$ sensing, $\mathrm{VIZ}=$ Violacein inhibition zone $(\mathrm{mm})$ and MID=Minimum inhibitory dose (mg/disc). Extract concentrations used for determining VIZ and MID were 1 and $2 \mathrm{mg} /$ disc, respectively

\section{CONCLUSION}

Of the 12 spices studied, clove is the king in terms of antioxidant, antibacterial and anti-QS properties. Cinnamon ranked first in anti-tyrosinase, second in antioxidant properties and possessed all four bioactivities. This study has demonstrated the therapeutic benefits of spices, which are retained even after cooking. Noteworthy is the enhancement effect of heat treatment on the antioxidant properties of cardamom and clove, and on the antibacterial properties of cardamom and cinnamon. The ability of cinnamon to inhibit E. coli only after cooking deserves special mention. The effects of heat treatment on the anti-tyrosinase and anti-QS activities of spices are reported for the first time in this study. Further research is needed to understand how the different heat treatments affect the composition and structure of phytochemicals in spices. Using a combination of spices in cooking may result in improved bioactivities, which will help to promote nutritional health. However, the role of spices as functional food, the efficacy of value-added products such as essential oils and the synergistic effects of their bioactive compounds have to be determined.

\section{Author contributions}

H. J. C., J. E. L., S. H. Y., S. F. T., P. C. G., K. Y. Y. and S. Y. Y. jointly conducted the research and compiled the data; described the methodology; and presented the results, discussion and conclusion in their theses. E. W. C. C. is the lead scientist, supervisor and corresponding author.

\section{REFERENCES}

Aparna, Y., S. U. Kranthi and J. Sarada. 2014a. Syzygium aromaticum - A common food spice with potential quorum quenching activity on Serratia sp. YAJS. Int. J. Curr. Microbiol. Appl. Sci. 3(7): 93-102.

Aparna, Y., L. Narayanan and J. Sarada. 2014b. Quorum quenching ability of dietary spice Cinnamomum verum on pathogenic bacteria. Int. J. Pharm. Sci. Res. 5(12): 5216-5223.

Apriliany, F., H. Anshory and T. Hertiani. 2013. Anti-quorum sensing activity of kayu manis leaves extracts (Cinnamomum burmannii Ness. ex Bl.) against Pseudomonas aeruginosa. Tradit. Med. J. 18(3): 173-177.

Arazo M., A. Bello, L. Rastrelli, M. Montelier, L. Delgado and C.
Panfet. 2011. Antioxidant properties of pulp and peel of yellow mangosteen fruits. Emirates J. Food Agric. 23(6): 517-524.

Balasasirekha, R. 2014. Spices - The spice of life. Eur. J. Food Sci. Technol. 2(1): 29-40.

Bembem, K. and B. Sadana. 2013. Effect of cooking methods on the nutritional composition antioxidant activity of potato tubers. Int. J. Food Nutr. Sci. 2(4): 26-30.

Chan, E. W. C., Y. Y. Lim, S. K. Wong, K. K. Lim, S. P. Tan, F. S. Lianto and M. Y. Yong. 2009. Effects of different drying methods on the antioxidant properties of leaves and tea of ginger species. Food Chem. 113(1): 166-172.

Chan, E. W. C., L. Q. Kong, K. Y. Yee, W. Y. Chua and T. Y. Loo. 2012. Antioxidant and antibacterial properties of some fresh and dried Labiatae herbs. Free Radic. Antioxid. 2: 20-27.

Chan, E. W. C., P. Y. Lye, S. Y. Eng and Y. P. Tan. 2013. Antioxidant properties of herbs with enhancement effects of drying treatments: A synopsis. Free Radic. Antioxid. 3(1): 2-6.

Chan, E. W. C., Y. P. Tan, S. J. Chin, L. Y. Gan, K. X. Kang, C. H. Fong, H. Q. Chang and Y. C. How. 2014. Antioxidant properties of selected fresh and processed herbs and vegetables. Free Radic. Antioxid. 4(1): 39-46.

Choi, Y., S. M. Lee, J. Chun, H. B. Lee and J. Lee. 2006. Influence of heat treatment on the antioxidant activities and polyphenolic compounds of Shiitake (Lentinus edodes) mushroom. Food Chem. 99(2): 381-387.

Dewanto, V., X. Z. Wu, K. K. Adom and R. H. Liu. 2002a. Thermal processing enhances the nutritional value of tomatoes by increasing total antioxidant activity. J. Agric. Food Chem. 50: 3010-3014.

Dewanto, V., X. Z. Wu and R. H. Liu. 2002b. Processed sweet corn has higher antioxidant activity. J. Agric. Food Chem. 50: 49594964.

Ismail, A., Z. M. Marjan and C. W. Foong. 2004. Total antioxidant activity and phenolic content in selected vegetables. Food Chem. 87: 581-586.

Kang, K. S., H. Y. Kim, J. S. Pyo and T. Yokozawa. 2009. Increase in the free radical scavenging activity of ginseng by heat processing. Biol. Pharm. Bull. 29: 750-754.

Khan, M. S., M. Zahin, S. Hasan, F. M. Husain and I. Ahmad. 2009. Inhibition of quorum sensing regulated bacterial functions by plant essential oils with special reference to clove oil. Lett. Appl. Microbiol. 49(3): 354-360.

Khatun, M., S. Eguchi, T. Yamaguchi, H. Takamura and T. Matoba. 2006. Effect of thermal treatment on radical-scavenging activity of some spices. Food Sci. Technol. Res. 12(3): 175-185.

Koh, K. H. and F. Y. Tham. 2011. Screening of traditional Chinese medicinal plants for quorum-sensing inhibitors activity. J. Microbiol. Immun. Infect. 44: 144-148.

Larrauri, J. A., P. Rupérez and F. Saura-Calixto. 1997. Effect of drying temperature the stability of polyphenols and antioxidant activity of red grape pomace peels. J. Agric. Food Chem. 45: 13901393.

Lim, Y. Y. and J. Murtijaya. 2007. Antioxidant properties of Phyllanthus amarus extracts as affected by different drying methods. LWT Food Sci. Technol. 40: 1664-1669.

Masuda, T., D. Yamashita, Y. Takeda and S. Yonemori. 2005. Screening for tyrosinase inhibitors among extracts of seashore plants and identification of potent inhibitors from Garcinia subelliptica. Biosci. Biotechnol. Biochem. 69(1): 197-201.

Milind, P. and K. Deepa. 2011. Clove: A champion spice. Int. J. Res. Ayurveda Pharm. 2(1): 47-54.

Mishra, N. and K. K. Behal. 2010. Antimicrobial activity of some 
spices against selected microbes. Int. J. Pharm. Pharm. Sci. 2(3): 187-196.

Nicoli, M. C., M. Anese and M. Parpinel. 1999. Influence of processing on the antioxidant properties of fruits and vegetables. Trends Food Sci. Technol. 10: 94-100.

Packiavathy, I. A. S. V., P. Agilandeswari, K. S. Musthafa, S. K. Pandian and A. V. Ravi. 2012. Antibiofilm and quorum sensing inhibitory potential of Cuminum cyminum and its secondary metabolite methyl eugenol against gram-negative bacterial pathogens. Food Res. Int. 45: 85-92.

Roy, M. K., M. Takenaka and T. Tsushida. 2007. Antioxidant potential, antiproliferative activities, and phenolic content in water-soluble fractions of some commonly consumed vegetables: Effects of thermal treatment. Food Chem. 103: 106-114.

Saikia, S. and C. L. Mahanta. 2013. Effect of steaming, boiling and microwave cooking on the total phenolics, flavonoids and antioxidant properties of different vegetables of Assam, India. Int. J. Food Nutr. Sci. 2(3): 47-53.

Sethi, S., A. Dutta, B. L. Gupta and S. Gupta. 2013. Antimicrobial activity of spices against isolated food borne pathogens. Int. J. Pharm. Pharm. Sci. 5(1): 260-262.

Shan, B., Y. Z. Cai, M. Sun and H. Corke. 2005. Antioxidant capacity of 26 spice extracts and characterization of their phenolic constituents. J. Agric. Food Chem. 53(20): 7749-7759.

Shan, B., Y. Z. Cai, J. D. Brooks and H. Corke. 2007. The in vitro antibacterial activity of dietary spice and medicinal herb extracts. Int. J. Food Microbiol. 117: 112-119.
Shobana, S. and K. A. Naidu. 2000. Antioxidant activity of selected Indian spices. Prostag. Leuko. Essen. Fatty Acids. 62(2): 107-110.

Tan, Y. P. and E. W. C. Chan. 2014. Antioxidant, antityrosinase and antibacterial properties of fresh and processed leaves of Anacardium occidentale and Piper betle. Food Biosci. 6: 17-23.

Tan, Y. P., E. W. C. Chan and C. S. Y. Lim. 2015. Potent quorum sensing inhibition by methyl gallate isolated from leaves of Anacardium occidentale L. (cashew). Chiang Mai J. Sci. (In Press).

Tomaino, A., F. Cimino, V. Zimbalatti, V. Venuti, V. Sulfaro, A. de Pasquale and A. Saija. 2005. Influence of heating on antioxidant activity and the chemical composition of some spice essential oils. Food Chem. 89(4): 549-554.

Turkmen, N., R. Sari and Y. S. Velioglu. 2005. The effect of cooking methods on total phenolics and antioxidant activity of selected green vegetables. Food Chem. 93: 713-718.

Yoshino, K. 2010. Malaysian cuisine: A case of neglected culinary globalization. In: Farrer, J. (Ed.). Globalization, Food and Social Identities in the Asia Pacific Region. Institute of Comparative Culture, Sophia University, Tokyo, Japan. Available from: http://www.icc.fla.sophia.ac.jp/global\%20food\%20papers/html/ yoshino.html. [Last retrieved on 2015 Jun 02].

Zhang, D. and Y. Hamauzu. 2004. Phenolics, ascorbic acid, carotenoids and antioxidant activity of broccoli and their changes during conventional and microwave cooking. Food Chem. 88: 503-509. 